\title{
PETROLOGY AND GEOCHEMISTRY OF GRANITIC PEBBLES IN THE PARNASSOS FLYSCH AT ITI MOUNTAIN, CONTINENTAL CENTRAL GREECE
}

\author{
Karipi S. ${ }^{1}$, Tsikouras B. ${ }^{1}$, and Hatzipanagiotou K. ${ }^{1}$ \\ 1 University of Patras, Department of Geology, Section of Earth Materials, GR-26 500 Patras, \\ Greece,skaripi@upatras.gr,v.tsikouras@upatras.gr,K.Hatzipanagiotou@upatras.gr
}

\begin{abstract}
Granite rocks occur as pebbles within the Parnassos flysch deposits, in the area of Iti (Central Greece). The granites are peraluminous, calcic rocks with $S$-type characteristics. Geochemical features reveal that these rocks are not co-genetic to the Iti ophiolite but they have been derived from magmas affected by a subduction component. They display common characteristics with VAG-type lithologies. Geochemically, they mostly resemble nearby granite clasts from a Triassic flyschoid from Evia (Liri Unit), and lesser those within the Parnassos flysch at Amfissa and Pliocene fluvial deposits at Patras.
\end{abstract}

Key words: granite pebbles, biotite, S-type, VAG.

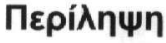

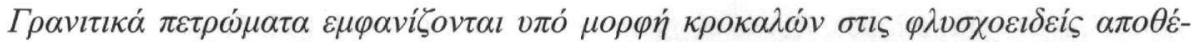

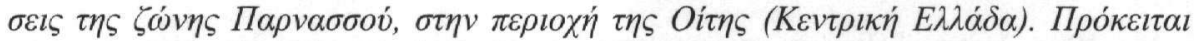

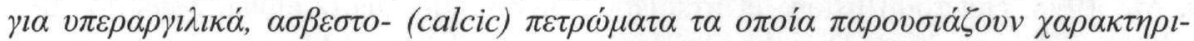

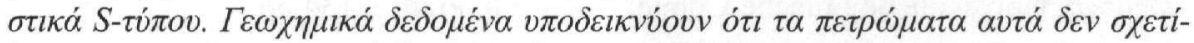

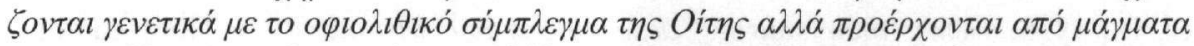

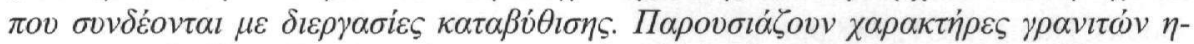

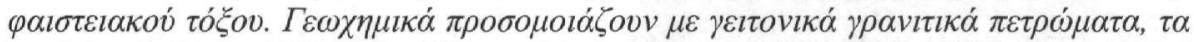

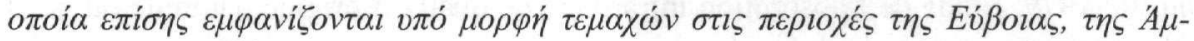
$\varphi l \sigma \sigma \alpha \varsigma \kappa \alpha l \tau \eta \varsigma \Pi \dot{\alpha} \tau p \alpha \varsigma$.

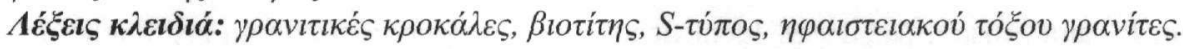

\section{Introduction}

Paleocene was a critical period for the Parnassos zone since it underwent extensive environmental and depositional changes. From Late Triassic to Late Cretaceous this zone existed as a carbonate platform with neritic and pelagic carbonate sedimentation (locally until early Paleocene) except for three short periods where deposition was interrupted (bauxite horizons). As a result of the tectonic activity in the inner zones, the deposition changed during Paleocene and became terrigenous (flysch) (Papastamatiou 1960, Celet 1962, Richter and Mariolakos 1974, Keupp 1976, Richter 1976, Solakius and Pomoni-Papaioannou 1992, Solakius 1994). The transition from carbonate to flysch facies took place at the latest Maastrichtian-Middle Paleocene interval and was not continuous. The deposition of the flysch began all over Parnassos in the Late Paleocene (Solakious 
1994). Several authors (Papastamatiou 1960, Celet 1962, Richter and Mariolakos 1974, 1975, Richter 1976, Richter and Risch 1981) have described the general characteristics of the Parnassos flysch. According to Celet (1962), the flysch was subdivided into the red marly flysch (flysch rouge), the sandy-marly and marly-sandy flysch (rythmique pélitique and gréso-marneux flysch) and the conglomerates (flysch conglomeratique).

This paper presents new geochemical data on granite pebbles incorporated within the Parnassos flysch deposits, in the area of Iti. Our study aims to investigate their geochemistry and the geotectonic environment where these granite rocks were formed. Moreover, it compares them with other adjacent granites of known origin attempting to define a possible source for the granite pebbles.

\section{Geological Setting}

The Iti Mountain $\square$ lies to the south of Othrys Mountain and the Sperchios River, in continental Central Greece. It belongs to the "Pelagonia terrane" (Stampfli 1996, Stampfli et al. 1998) a carbonate platform, equivalent to the "Internal carbonate platform" of Papanikolaou (1989). The geological structure of the Iti Mountain includes four westward verging tectono-stratigraphic zones, representing different paleotectonic domains. They comprise, from west to east: the Pindos, Parnassos, Beotian and Pelagonian zones (Wigniolle 1977b). The Iti Mountain (Fig. 1) is composed of a stack of nappe units. From bottom to top, they include: (1) the flysch of the EastPindos syncline, (2) Mesozoic platform carbonates along with flysch of the Parnassos zone, (3) the Beotian flysch, (4) the Jurassic platform carbonates of the Pelagonian zone, and the overthrust ophiolite unit (Celet 1976, Celet et al. 1977, Richter et al. 1997). The latter includes a lower ophiolite mélange, which is locally, tectonically overlain by a sub-ophiolitic metamorphic sole (s). Both formations are overthrust by a remnant ophiolite nappe of upper mantle tectonites (harzburgite and lherzolite, Karipi 2004, Karipi et al. 2006). The ophiolite unit is transgressively overlain by Upper Cretaceous formations (Celet 1962, Wigniolle 1977b).

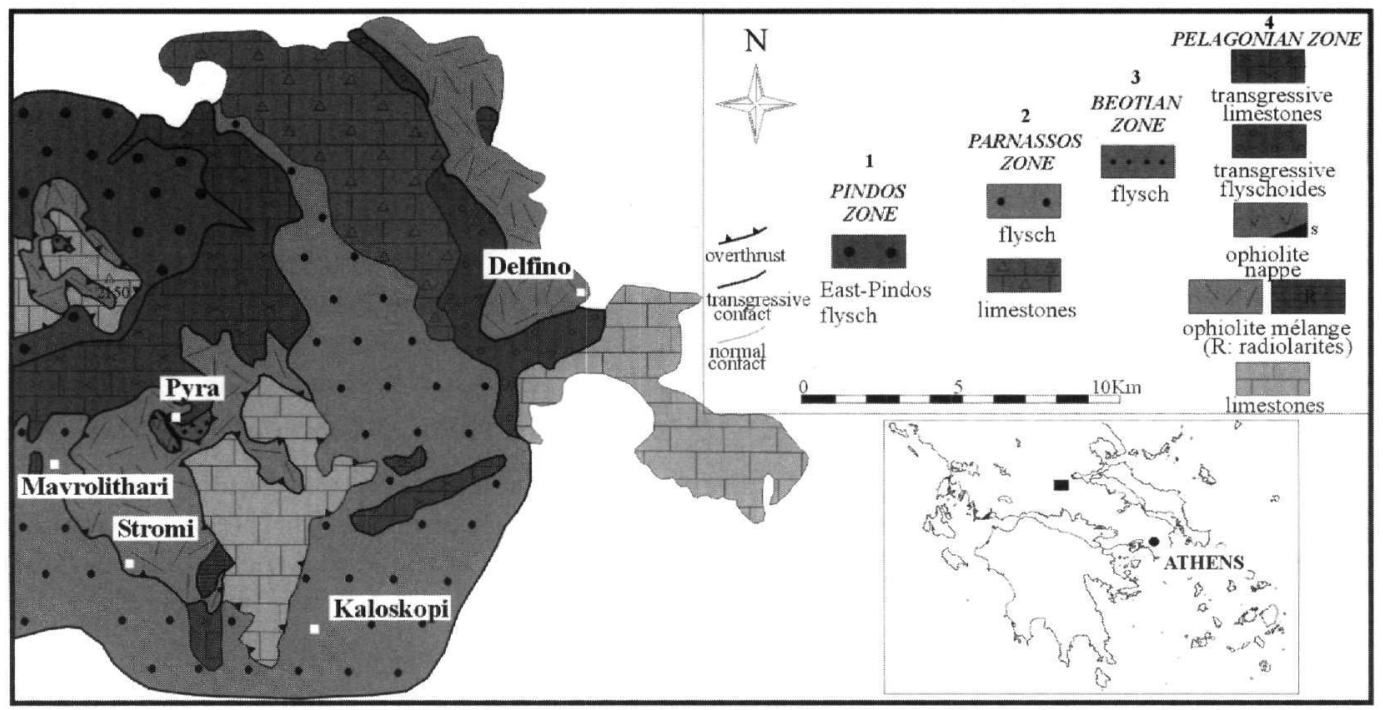

Figure 1 - Simplified geological map of the Iti Mountain

The Parnassos flysch is dominant in the Iti Mountain (Wigniolle 1977a) where its deposition took place during Eocene (Papastamatiou 1960, Papastamatiou et al. 1962). It consists of cyclic alternations of mudshales with intercalations of mudstones and siltstones, marls with sandstone beds and massive sandstones with intercalated shales. Towards the top, conglomerates consisting mainly of pebbles of sandstone, slate, limestone, chert and greenschist rocks occur, too (Gregou 
1994). Locally, lenticular limestone bodies are developed, in these upper layers (Papastamatiou et al. 1960). During fieldwork, we observed that minor amounts of pebbles and fragments of ophIolitic rocks (dolerite, serpentinite, gabbro) have also been incorporated into these conglomeratic flysch deposits, near the Kaloskopi and Mavrolithari villages. Granite pebbles were found near Kaloskopi village (Fig. 1). They are up to $60 \mathrm{~cm}$ in diameter and quite resistant to weathering.

\section{Petrography}

The granites show granular and pegmatite textures. Locally, they display consertal, poikilitic, granophyric and crossing textures. Their assemblage includes quartz (40-50 vol. \%), K-feldspar (25-30 vol. \%), plagioclase (10-15 vol. \%), biotite (10-15 vol. \%) and scarce muscovite in two samples; epidote, titanite, zircon, apatite and opaques occur as accessory minerals (Table 1).
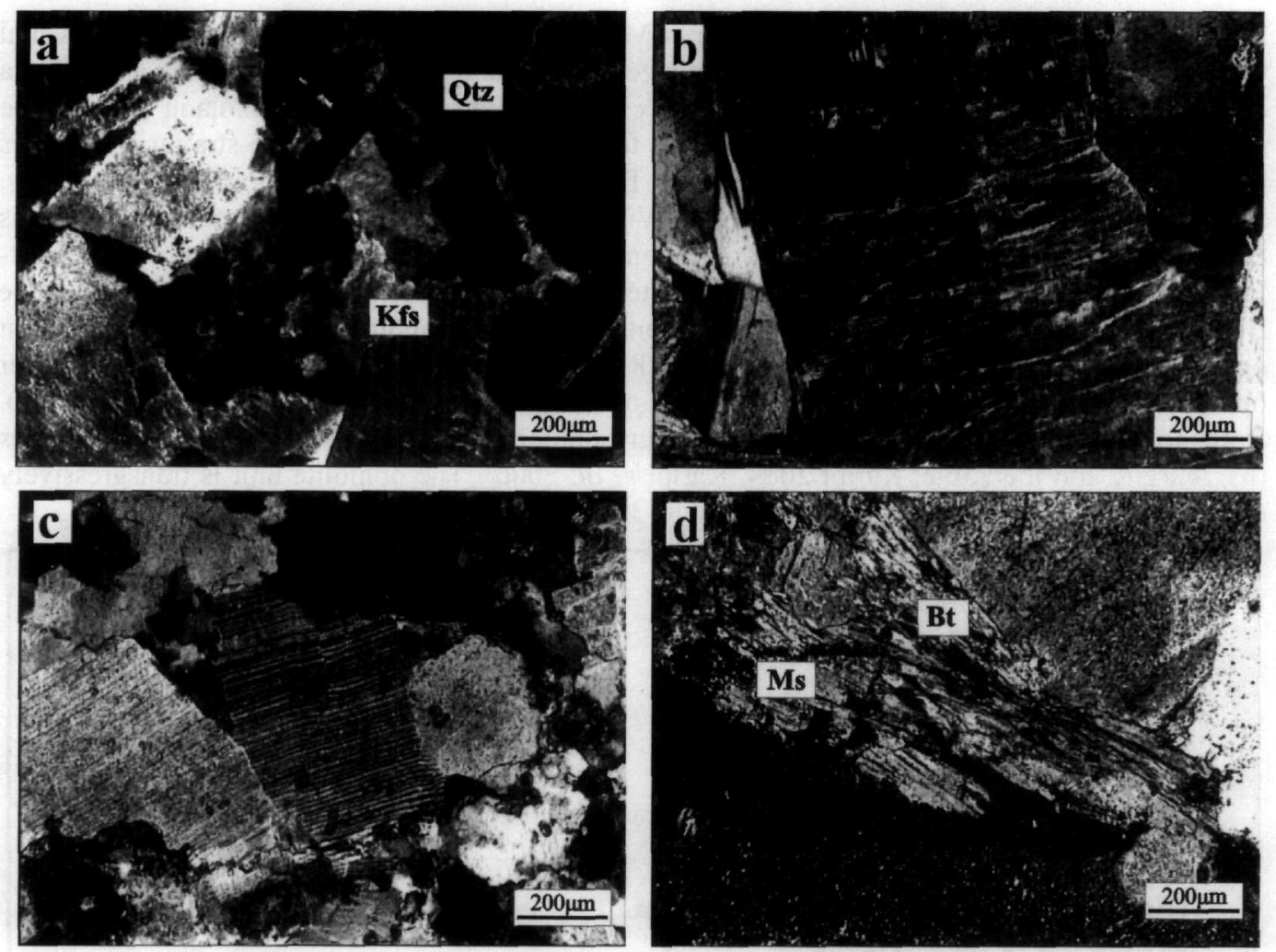

Figure 2 - Photomicrographs (XPL) showing: a. K-feldspar (Kfs) and quartz (Qtz) intergrowths in granophyric texture (sample $\mathrm{I}_{342}$ ) b. perthite crystal with Carlsbad twinning (sample $K_{1}$ ) c. microfracturing and minor dislocation glide of twins in a plagioclase crystal (sample $K_{1}$ ) d. aggregates of biotite (Bt) and muscovite (Ms) crystals (sample $K_{1}$ )

Quartz forms anhedral crystals $(0.5-5 \mathrm{~mm})$ with intergrown boundaries; fine aggregates of polycrystalline quartz were also observed. Quartz crystals frequently show undulose extinction due to intense deformation of the host-granite. K-feldspar occurs as subhedral crystals (1-5 mm) showing granophyric and perthitic intergrowths with quartz and albite (Figs 2a, b), respectively, as well as Carlsbad twinning (Fig. 2b). Several perthites are surrounded by narrow albite rims $(\sim 0.05 \mathrm{~mm})$. Plagioclase forms subhedral crystals $(0.6-3 \mathrm{~mm})$ and displays multiple twinning and zoning patterns (Fig. 2c). Some plagioclase crystals show brittle deformation features such as serrated grain boundaries, internal microfracturing and minor dislocation glide of twins (crude kinking; Fig. 2c). Biotite and rarely muscovite form subhedral to euhedral crystals $(0.3-1.5 \mathrm{~mm}$; Fig. $2 \mathrm{~d})$. The cleav- 
age in the biotite is frequently kinked. Both biotite and quartz crystals display locally a poikilitic texture. Biotite poikilitically contains zircon and/or apatite, whereas quartz encloses biotite. The opaque minerals are ilmenite, Mn-ilmenite and Fe-pseudobrookite. Pyrite is also present in minor amounts forming either euhedral to subhedral crystals or exsolved from biotite along its cleavage. $\mathrm{K}$-feldspar and plagioclase are altered to sericite and saussirite (epidote and clinozoisite), respectively. Biotite is replaced partially or entirely by chlorite and titanite.

Table 1 - Petrographic features of representative samples of the granite pebbles (qtz: quartz, PI: plagioclase, Kfs: K-feldspar, bt: biotite, ms: muscovite, ep: epidote, ap: apatite, zrn: zircon, ttn: titanite, chl: chlorite, ser: sericite, czo: clinozoisite, py: pyrite)

\begin{tabular}{|c|c|c|c|c|c|}
\hline $\begin{array}{c}\text { Rock } \\
\text { Sample }\end{array}$ & Texture & Assemblage & $\begin{array}{l}\text { Accessory } \\
\text { minerals }\end{array}$ & Alteration & $\begin{array}{c}\text { Other } \\
\text { features }\end{array}$ \\
\hline $\mathrm{I}_{342}$ & $\begin{array}{l}\text { granular, } \\
\text { granophyric, } \\
\text { poikilitic }\end{array}$ & $\begin{array}{l}\text { Qtz }(50 \%) \text {, Kfs }(30 \%) \text {, } \\
\text { Pl }(10 \%) \text {, bt }(8 \%)\end{array}$ & $\begin{array}{l}\text { Ep, ap, } \\
\mathrm{ttn}, \mathrm{zrn}, \\
\text { py }\end{array}$ & $\begin{array}{l}\mathrm{bt} \rightarrow \mathrm{chl}+\mathrm{ttn} \\
\mathrm{Kfs} \rightarrow \mathrm{ser} \\
\mathrm{Pl} \rightarrow \text { ser } \\
\mathrm{Pl} \rightarrow \text { ep }+ \text { czo }\end{array}$ & $\begin{array}{l}\mathrm{Pl} \text { zonation, } \\
\text { perthites }\end{array}$ \\
\hline $\mathrm{K}_{1}$ & $\begin{array}{l}\text { granular, } \\
\text { consertal, } \\
\text { poikilitic }\end{array}$ & $\begin{array}{l}\text { Qtz }(40 \%), \text { Kfs }(30 \%) \\
\text { Pl }(15 \%), \text { bt }+ \text { ms }(15 \%)\end{array}$ & $\begin{array}{l}\mathrm{ttn}, \mathrm{Fe}-\mathrm{Ti} \\
\text { oxides }\end{array}$ & $\begin{array}{l}\mathrm{Pl} \rightarrow \text { ser } \\
\mathrm{bt} \rightarrow \mathrm{chl}\end{array}$ & $\begin{array}{l}\text { Bt kinking, PI zona- } \\
\text { tion, perthites, } \\
\text { Carlsbad twinning, } \\
\text { polycrystalline Qtz }\end{array}$ \\
\hline Pan & pegmatitic & $\begin{array}{l}\text { Qtz }(45 \%), \text { Kfs }(25 \%) \\
\text { Pl }(15 \%), \text { bt }+ \text { ms }(15 \%)\end{array}$ & $\begin{array}{l}\mathrm{ttn}, \mathrm{Fe}-\mathrm{Ti} \\
\text { oxides, ap }\end{array}$ & $\begin{array}{l}\mathrm{Pl} \rightarrow \text { ser } \\
\mathrm{Pl} \rightarrow \text { ep } \\
\mathrm{bt} \rightarrow \mathrm{chl}\end{array}$ & Perthites \\
\hline
\end{tabular}

\section{Analytical Methods}

Electron microanalyses were carried out at the Laboratory of Electron Microscopy and Microanalysis, University of Patras, using a Jeol JSM-6300 SEM, equipped with EDS and WDS and a THETA software. Operating conditions were $15 \mathrm{kV}$ accelerating voltage and $3.3 \mathrm{nA}$ beam current. Whole-rock chemical analyses were performed at Department of Geosciences of Bristol University (Great Britain), on a Spectro Analytical X-Lab 2000 X-ray fluorescence for major elements, trace elements and light rare earth elements ( $L R E E)$. Detection limit for major elements is $0.01 \%$, except for $\mathrm{TiO}_{2}$ and $\mathrm{MnO}$ which is $0.001 \%$.

\section{Mineral Chemistry}

\subsection{Biotite}

Biotite is the dominant primary ferromagnesian mineral analyzed in the granitic pebbles. Iron content in biotite ranges from $16.48 \%$ to $18.94 \%$ in sample $\mathrm{I}_{342}$, whereas it displays higher values $\left(26.78-27.78 \%\right.$ ) in sample $\mathrm{K}_{1}$ (Table 2$)$. $\mathrm{MgO}$ content is lower (7.05-8.73\%) in sample $\mathrm{K}_{1}$ and higher (11.09-12.18\%) in sample $\mathrm{I}_{342}$. On an $\mathrm{Al}^{\mathrm{IV}}$ vs. $\mathrm{Fe}^{2+} /\left(\mathrm{Fe}^{2+}+\mathrm{Mg}\right)$ diagram, plots of biotite from the two samples fall in two distinct fields (Fig. 3a). Biotites from sample $\mathrm{K}_{1}$ plot within "biotite + muscovite" field while biotites from sample $\mathrm{I}_{342}$ having lower $\mathrm{Fe}^{2+} /\left(\mathrm{Fe}^{2+}+\mathrm{Mg}\right)$ ratios fall in the "biotite only" field which is compatible to the petrographic observations. In general, the Al content in biotite co-existed with muscovite is higher in comparison to this in biotite associated to amphibole. According to Honma (1974), Boak and Dymek (1982), Labotka (1983), the whole chemistry of biotite is strongly affected by the co-existed mineral phases such as muscovite and amphibole, resulting in different $\mathrm{Al}$ saturation in biotite. The freshest biotite crystals analyzed contain high $\mathrm{Ti}(>4 \%)$ and only where there has been some alteration, both $\mathrm{Ti}$ and $\mathrm{K}$ decreaSe (Table 2). On the discrimination diagrams after Abdel-Rahmann (1994), the analyzed biotites from the granites fall in the range of calc-alkaline rocks (Figs 3b-d). 

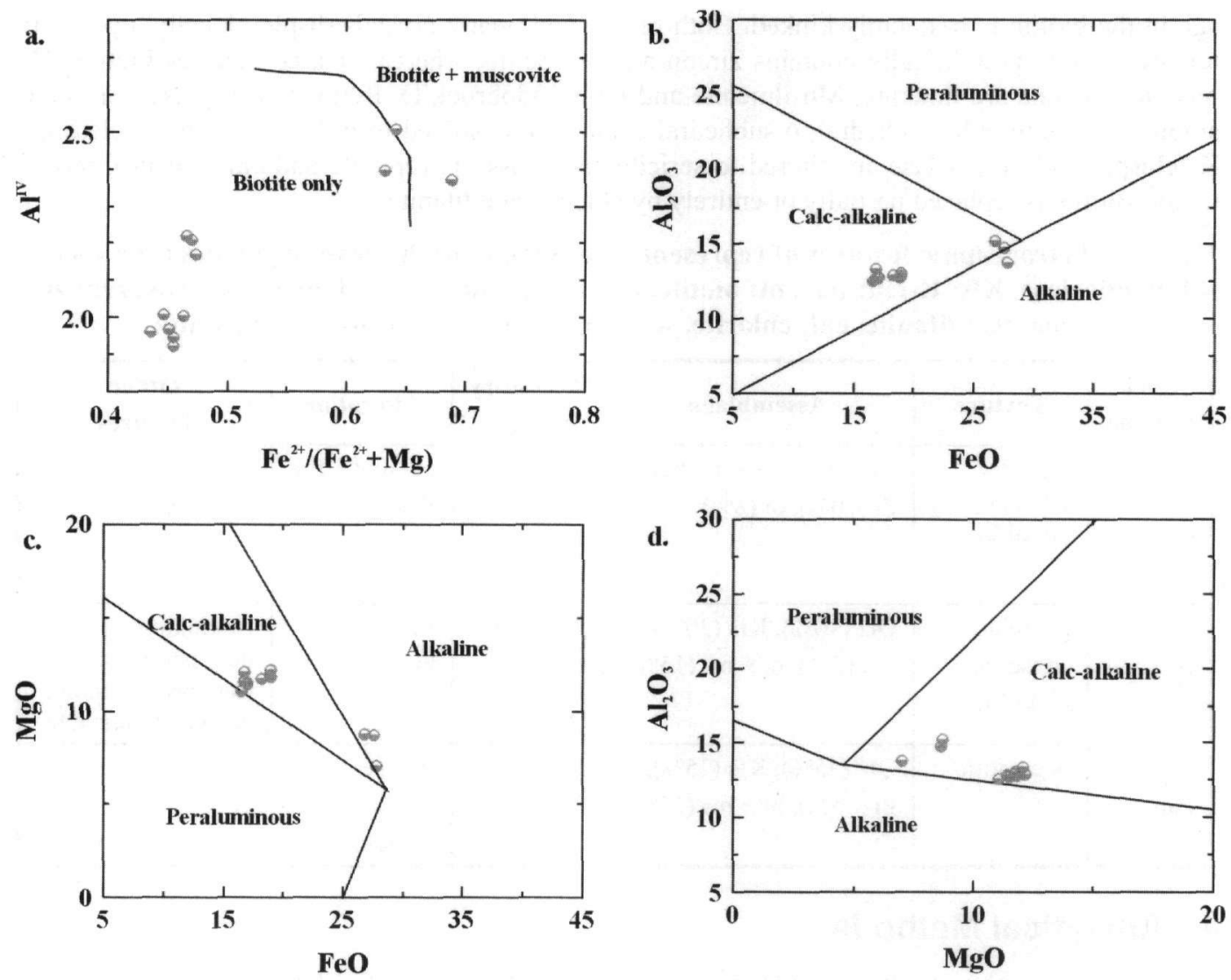

Figure 3 - Plots illustrating chemical variations in the analyzed biotites a. $\mathrm{Al}^{\mathrm{IV}}$ vs. $\left(\mathrm{Fe}^{2+} / \mathrm{Fe}^{2+}+\mathrm{Mg}\right)$ diagram. Fields of biotite only and biotite + muscovite from Clarke (1981) bd. variations in $\mathrm{Al}_{2} \mathrm{O}_{3}, \mathrm{FeO}$ and $\mathrm{MgO}$ on the Abdel-Rahman (1994) discrimination diagrams

\subsection{Chlorite}

Chlorite analyses plot mostly in the brunsvigite and pycnochlorite fields on the classification diagram of chlorites (after Hey 1954; not shown). Only two analyses fall in the diabantite field. The chemistry of chlorite seems to follow the chemistry of the precursor biotite. Thus, chlorite after biotite richer in iron content (sample $\mathrm{K}_{1}$ ) contains higher $\mathrm{Fe}(26.00-33.30 \%)$ in comparison to the chlorite replacing biotite poorer in iron content that displays lower Fe values $(<26 \%$; Table 2).

\subsection{Feldspar}

Most of the analyzed alkali feldspars are rich in orthoclase content whereas few crystals contain significant $\mathrm{Ab}$ contents. The analyzed crystals of plagioclase are albites (Table 2).

\subsection{Opaque minerals}

Electron microanalyses indicate that ilmenite, Mn-ilmenite and Fe-pseudobrookite are the Fe-Ti oxides present in the granite pebbles. Mn-ilmenites contain significant MnO contents (12-17 wt. \%; Table 2). The pyrophanite content $\left(\mathrm{MnTiO}_{3}\right)$ generally increases in ilmenite from acid rocks as it is favoured during the process of magma differentiation (Deer et al. 1992). Fepseudobrookite is a secondary mineral forming after ilmenite and Mn-ilmenite under highly oxidizing conditions (Ottemann and Frenzel 1965, Bowles 1988). 


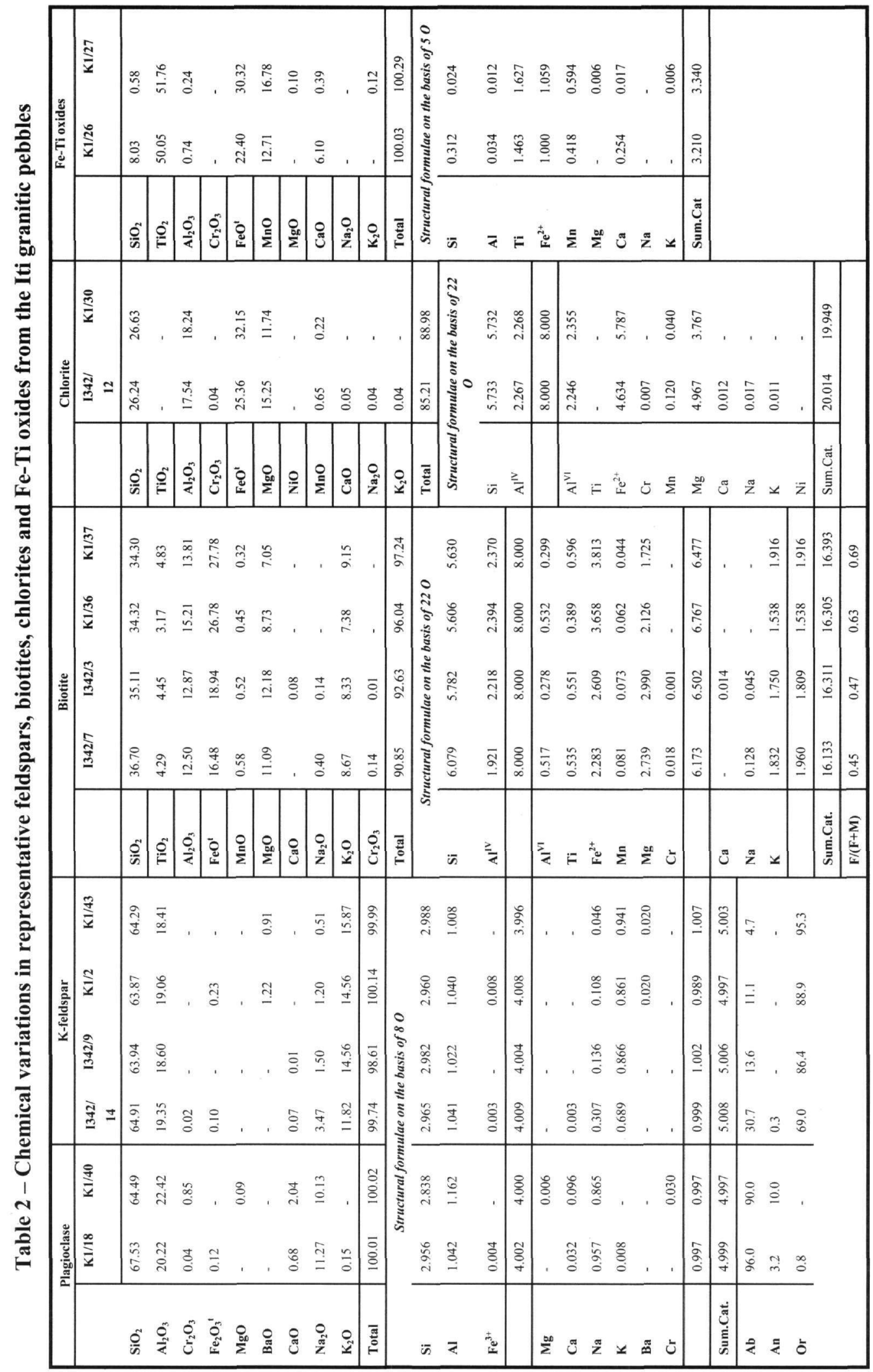


Table 3 - Whole-rock geochemical analyses of the granite pebbles from Iti

\begin{tabular}{|c|c|c|c|}
\hline $\begin{array}{l}\text { Rock } \\
\text { Sample }\end{array}$ & $\mathbf{I}_{342}$ & $\mathbf{K}_{\mathbf{1}}$ & Pan \\
\hline \multicolumn{4}{|c|}{ Major elements (wt \%) } \\
\hline $\mathrm{SiO}_{2}$ & 75.71 & 79.98 & 68.49 \\
\hline $\mathrm{TiO}_{2}$ & 0.18 & 0.12 & 0.18 \\
\hline $\mathbf{A l}_{2} \mathbf{O}_{3}$ & 13.71 & 11.36 & 12.82 \\
\hline $\mathrm{Fe}_{2} \mathrm{O}_{3}{ }^{\mathrm{t}}$ & 1.13 & 0.61 & 1.14 \\
\hline MnO & 0.02 & 0.01 & 0.03 \\
\hline MgO & 0.61 & 0.28 & 0.60 \\
\hline $\mathrm{CaO}$ & 0.65 & 0.42 & 0.53 \\
\hline $\mathrm{Na}_{2} \mathrm{O}$ & 3.30 & 2.90 & 2.96 \\
\hline $\mathbf{K}_{2} \mathbf{O}$ & 3.49 & 3.55 & 3.09 \\
\hline $\mathbf{P}_{2} \mathbf{O}_{5}$ & 0.06 & 0.03 & 0.07 \\
\hline L.O.I. & 0.80 & 0.69 & 9.93 \\
\hline Total & 99.66 & 99.95 & 99.84 \\
\hline \multicolumn{4}{|c|}{ Trace elements (ppm) } \\
\hline $\mathbf{R b}$ & 154 & 112 & 126 \\
\hline $\mathrm{Sr}$ & 108 & 168 & 157 \\
\hline$Y$ & 20 & 3 & 23 \\
\hline $\mathrm{Zr}$ & 117 & 82 & 126 \\
\hline $\mathrm{Nb}$ & 11 & 5 & 12 \\
\hline Ba & 633 & 1404 & 475 \\
\hline Th & 20 & 14 & 16 \\
\hline Ta & 4 & 2 & 6 \\
\hline Hf & 3 & 0.8 & 3 \\
\hline $\mathbf{U}$ & 2 & 2 & 2 \\
\hline \multicolumn{4}{|c|}{ LREE (ppm) } \\
\hline La & 34.00 & 35.00 & 29.00 \\
\hline $\mathrm{Ce}$ & 54.70 & 50.50 & 53.20 \\
\hline $\mathrm{Pr}$ & 20.00 & 24.00 & 16.00 \\
\hline Nd & 34.30 & 32.30 & 32.20 \\
\hline Sm & 3.40 & 4.50 & 3.10 \\
\hline \multicolumn{4}{|l|}{ C.I.P.W. } \\
\hline$q$ & 41.02 & 48.42 & 41.30 \\
\hline c & 3.50 & 2.07 & 4.24 \\
\hline or & 20.88 & 21.14 & 20.33 \\
\hline ab & 28.27 & 24.73 & 27.88 \\
\hline an & 2.87 & 1.90 & 2.42 \\
\hline ne & - & - & - \\
\hline di & - & - & - \\
\hline hy & 2.66 & 1.26 & 2.92 \\
\hline ol & - & - & - \\
\hline $\mathrm{mt}$ & 0.29 & 0.16 & 0.33 \\
\hline il & 0.35 & 0.23 & 0.38 \\
\hline ap & 0.13 & 0.07 & 0.17 \\
\hline
\end{tabular}

\section{Whole-rock Geochemistry}

On the chemical classification system of Streckeisen and Le Maitre (1979), the studied rocks are classified as granites (not shown). They contain high $\mathrm{SiO}_{2}$ $(68.49-79.98 \%), \mathrm{Na}_{2} \mathrm{O}(2.90-3.30 \%)$ and $\mathrm{K}_{2} \mathrm{O}(3.09-$ $3.55 \%$ ) concentrations while they show depletion in $\mathrm{Fe}_{2} \mathrm{O}_{3}{ }^{\mathrm{t}}, \mathrm{MgO}$ and $\mathrm{CaO}$ (Table 3). The trace elements $\mathrm{Rb}, \mathrm{Ba}$ and $\mathrm{Sr}$ display high values (Table 3 ) as they are retained by the major mineral constituents of the granite assemblage, feldspars and biotite suggesting that mineral phases exercise a significant control on elemental distribution in the rock (Hanson 1978). The analyzed granite pebbles do not resemble plagiogranites found in ophiolite complexes since their normative orthoclase and $\mathrm{K}_{2} \mathrm{O}$ contents exceed the percentages of $4 \%$ and $1 \%$, respectively (see Table 3 ), thus suggesting that they are not co-genetic to the Iti ophiolite. The studied granite is peraluminous with molar $\mathrm{A} / \mathrm{CNK}$ ratio within the range of 1.21-1.40 (Fig. 4a) and displays S-type characteristics after the criteria of Chappell and White (1974) and White and Chappell $(1977,1983)$. The Stype characteristics are summarized as: molar proportions of $\mathrm{Al}_{2} \mathrm{O}_{3} /\left(\mathrm{Na}_{2} \mathrm{O}+\mathrm{K}_{2} \mathrm{O}+\mathrm{CaO}\right)>1.1$, relatively low $(<3.2 \%) \mathrm{Na}_{2} \mathrm{O}$ contents, normative corundum $>1 \%$ and muscovite as a common mineral phase. However, the presence of titanite as an accessory mineral is characteristic of I-type granites. According to the alkali-lime index (Peacock's index), the granite rocks are also characterized as calcic with $\mathrm{SiO}_{2}>61 \%$. The chemistry of the granites can be successfully used to discriminate between various tectonic environments. Thus, using the tectonic environment discriminant diagrams of Pearce et al. (1984), the granitic rocks resemble volcanic arc granites (VAG) (Fig. 4b). Moreover, distributions of trace elements of the studied granites normalized to ocean ridge granite (ORG; Pearce et al. 1984) showing normalized $\mathrm{Hf} / \mathrm{Yb}<1$ and enrichments in LILE (Fig. 5a), are similar to patterns of volcanic arc granites. Similarly, spiderdiagrams of trace element distribution in the granitic rocks show a calc-alkalinetype profile characterized by depletion in $\mathrm{Nb}$ and $\mathrm{Ti}$, features that are suggestive of a subduction-related origin for the granitic rocks (Fig. 5b).

\section{Discussion}

Granite rocks in the area of Iti were found exclusively as pebbles within the Parnassos flysch deposits. Petrographic observations and geochemical data indicate that these granites may have been 
derived by partial melting of sedimentary source material as they mainly display S-type characteristics. Moreover, they show calc-alkaline-type profile by demonstrating selective enrichment in LIL elements while they are characterized by a general depletion in HFS elements which is thought to be typical of VAG-type derived from magmas affected by a subduction component. Besides, depletion in $\mathrm{Nb}, \mathrm{Hf}$, Ti and $\mathrm{P}$ is also suggestive of subduction process as it can be attributed to mineral phases like titanite, zircon, apatite that were crystallized and remained under high $\mathrm{P}_{\mathrm{H} 2 \mathrm{O}}$ (Wilson 1989, Thompson et al. 1997).
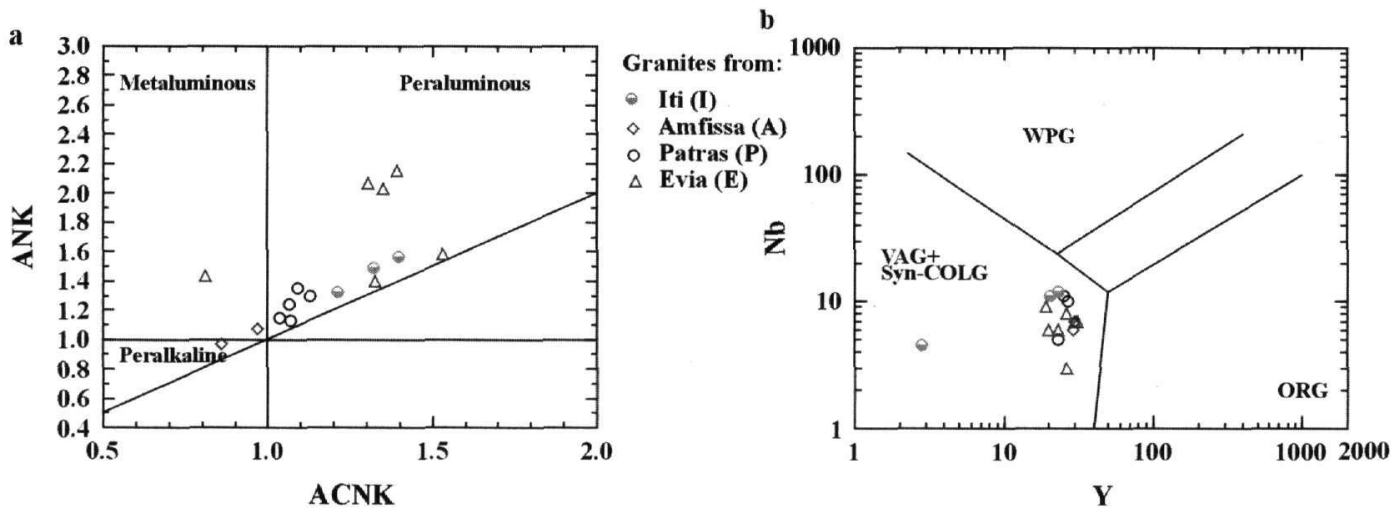

Figure 4 - a. Shand's index or $\mathrm{Al}_{2} \mathrm{O}_{3} /\left(\mathrm{Na}_{2} \mathrm{O}+\mathrm{K}_{2} \mathrm{O}\right)[\mathrm{A} / \mathrm{NK}]$ vs. $\mathrm{Al}_{2} \mathrm{O}_{3} /\left(\mathrm{CaO}+\mathrm{Na}_{2} \mathrm{O}+\mathrm{K}_{2} \mathrm{O}\right)$ [ACNK] (Maniar and Piccoli 1989) b. geotectonic discrimination diagram after Pearce et al. (1984); WPG: within plate granites, ORG: ocean ridge granites, VAG: volcanic arc granites, Syn-COLG: syn-collision granites. Data for granites from Amfissa, Patras and Evia are from Pe-Piper and Koukouvelas (1990, 1992), De Bono (1998)

Similar nearby formations of granitic rocks as pebbles in Pliocene deposits have been reported by Pe-Piper and Koukouvelas $(1990,1992)$ in the areas of Patras and Amfissa, as well as by De Bono (1998) from the Liri Unit in Evia. In the area of Patras, the granitic rocks classified as granites, alkali-feldspar granites and tonalites, are slighty peraluminous with trace elements normalized patterns typical of volcanic arc granites (Pe-piper and Koukouvelas 1990; Figs 5a, b). According to Pe-Piper and Koukouvelas (1992), the granitic pebbles within the Parnassos flysch near Amfissa are leucogranites, which are classified as volcanic arc granites. Their trace elements distribution is consistent to VAG (Figs 5a, b). The "Liri granites" of De Bono (1998) are incorporated in the Liri Unit, a Triassic flyschoid sequence outcropping only in central Evia (Stampfli 1996, De Bono et al. 1998). The "Liri granites" display similar geochemical features (Figs 5a, b) with the granites from Patras and Amfissa and are classified as volcanic arc granites.

A comparative study between the granitic pebbles from Iti and the granitic clasts from Patras, Amfissa and Evia reveals the existence of common petrographic and geochemical characteristics for these rocks. The presence of biotite as the dominant mafic mineral phase in most of the granitic assemblages results from petrographic observations. The granites from Patras, Amfissa and Evia display high $\mathrm{K}_{2} \mathrm{O}$ contents $(>1 \%$ ), plot in the peraluminous field (Fig. 4a) and are characterized as calcic with $\mathrm{SiO}_{2}>61 \%$, similarly to those from Iti. On the discriminant diagrams of Pearce et al. (1984), they plot along with the Iti granites in the VAG field (Fig. 4b). The granites from Patras, Amfissa and Evia show calc-alkaline-type profiles (Figs 5a, b) similar to those from Iti.

The granite clasts from Patras and Amfissa areas, according to Pe-Piper and Koukouvelas (1990, 1992) have probably been originated from different sources. The pebbles in the area of Patras may have been derived from a thrust slice of basal Pindos igneous rocks formerly exposed in the frontal thrusts of the Pindos nappe and later removed by erosion (Pe-Piper and Koukouvelas 1990). These pebbles provide information on the occurrence of Late Triassic plutonic rocks generated during a back-arc volcanic event associated with rifting of the Pindos zone. Clasts from Amfissa may 
represent remnants of a middle Jurassic oceanic island arc developed within the Pindos Ocean at the leading edge of the oceanic plate within which the ophiolites were formed (Pe-Piper and Koukouvelas 1992). However, for both Patras and Amfissa granites there is not a completely clear theory for their origin. According to De Bono (1998), the granite blocks within the Liri Unit in Evia display the same ages ( $c a .310 \mathrm{Ma}$ ) and geochemical features as the typical Pelagonian basement, dated by Yarwood and Aftalion (1976), Engel and Reischmann (1998) and Vavassis et al. (1999) suggesting that these granites were originated from the Pelagonian basement.
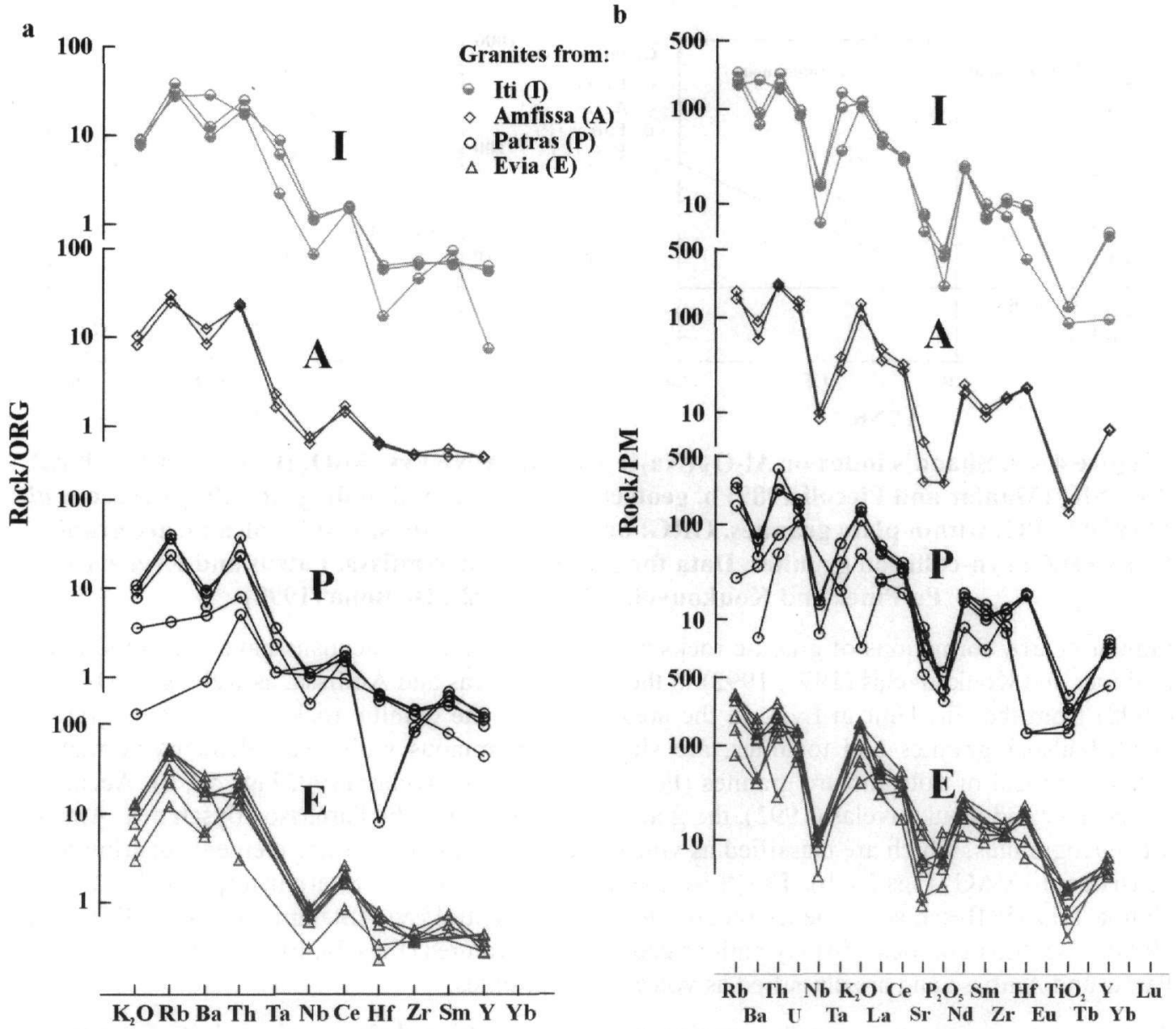

Figure 5 - a. Ocean ridge granite (ORG) normalized patterns of Iti (I), Amfissa (A), Patras (P) and Evia (E) granites. Normalizing values after Pearce et al. (1984) b. Primitive mantle (PM) normalized patterns of Iti, Amfissa, Patras and Evia granites. Normalizing values after (Sun and McDonough 1989). Data for granites from Amfissa, Patras and Evia are from PePiper and Koukouvelas $(1990,1992)$ and De Bono (1998)

The granite clasts from the areas of Patras and Amfissa, represent variably deformed and altered rocks (Pe-Piper and Koukouvelas 1990, 1992). The granite blocks in Evia, according to De Bono (1998), are always strongly altered and often cataclastic. They are incorporated within the Liri Unit that has been affected by low greenschist metamorphism and strong (Alpine?) deformation. The Pelagonian basement granites that are considered as the source material of the "Liri granites" have also undergone low-grade metamorphism and strong deformation (De Bono 1998). Similarly, the Iti granites have been experienced alteration at greenschist phases conditions coupled with some amount of brittle deformation that resulted in the development of grain-scale deformation features (e.g. undulose extinction, serrated grain boundaries, crude kinking). 
The Iti granites were found within the conglomeratic part of the Parnassos flysch, similarly to those found in Amfissa. According to Celet (1962), clasts of granites, diorites etc. contained in the Parnassos flysch deposits are thought to have been derived from the Pelagonian zone. Though, the Iti granite pebbles generally show geochemical resemblance with all Evia, Amfissa and Patras granite clasts, they probably match geochemically better to the Evia granite clastss, as it is shown by their normalized patterns (Figs 5a, b). However, the theory for the potential source of the Iti granites is strongly dependent on radiometric dating that is so far not available for the studied granites.

\section{Conclusions}

Granite pebbles were found in the Parnassos flysch at Iti Mountain. The petrological results of the present study and the comparison of these pebbles with analogous lithologies from Evia, Amfissa and Patras, are summarized as:

- The Iti granite pebbles are enriched in $\mathrm{K}_{2} \mathrm{O}, \mathrm{Na}_{2} \mathrm{O}, \mathrm{Rb}, \mathrm{Sr}, \mathrm{Ba}$ and $\mathrm{Zr}$ and show calcalkaline-type normalized patterns depleted in $\mathrm{Nb}, \mathrm{Hf}$, $\mathrm{Ti}$ and $\mathrm{P}$, suggestive of a subductionrelated origin

- They show rather high $\mathrm{K}_{2} \mathrm{O}>1 \%$ and orthoclase content $>4 \%$, hence are not considered as typical plagiogranites, thus, their genesis is unrelated to the Iti ophiolite complex

- They may have been derived by partial melting of sedimentary source material as it is indicated by their S-type characteristics

- They resemble VAG-type lithologies

- The Iti granite pebbles resemble petrographically and geochemically granite clasts from Evia, Patras and Amfissa, and they may either have been derived from the Pelagonian basement or from an island arc developed within the Pindos ocean.

\section{Acknowledgements}

The first author is thankful to the Greek Scholarship Foundation (IKY) for the financial support during her PhD study; financial support from the Research Committee of the University of Patras through the basic research supporting "Caratheodore" program, is gratefully acknowledged. We w ould also like to thank Prof. Dr. B.J. Wood and the researchers of the University of Bristol, Depart ment of Earth Sciences, for their assistance in elaborating whole-rock analyses, under financial sup port of a TMR Programme. Critical reviews by Dr. I. Boska and anonymous reviewer are gratefully acknowledged.

\section{References}

Abdel-Rahman, A.F.M., 1994. Nature of biotites from alkaline, calk-alkaline and peraluminous magmas, Journal of Petrology, 35, 525-1029.

Boak, J.L., and Dymek, R.F., 1982. Metamorphism of ca. 3800 Ma supracrustal rocks at Isua, West Greenland. Implications for early Archean crustal evolution. Earth and Planetary Science Letters, 59, 155-176.

Bowles, J.F.W., 1988. Definition and range of composition of naturally occurring minerals with the pseudobrookite structure, American Mineralogist, 73, 1377-1383.

Celet, P., 1962. Contribution à l'étude géologique du Parnasse-Kiona et d'une partie des regions méridionales de la Grèce continentale, Annalles Géologiques des Pays Helléniques, 13, 446pp. 
Celet, P., 1976. À propos du mélange de type "volcano-sédimentaire" de l'Iti (Grèce méridionale), Bulletin de la Société Géologique de France, 18, 299-307.

Celet, P., Ferrière, J., and Wigniolle, E., 1977. Le problème de l'origine des blocs exogènes du mélange à elements ophiolitiques au Sud du Sperchios et dans le massif de l'Othrys (Grèce), Bulletin de la Société Géologique de France, 19(4), 935-942.

Chappell, B.W., and White, A.J.R., 1974. Two contrasting granite types, Pacific Geology, 8, 173174.

Clarke, D.B., 1981. The mineralogy of peraluminous granites: A review, Canadian Mineralogist, 19, 3-17.

De Bono, A., 1998. Pelagonian margins in central Evia island (Greece). Stratigraphy and geodynamic evolution, Thèse de doctorat, Université de Lausanne, 114pp.

De Bono, A., Vavassis, I., and Stampfli, G.M., 1998. A Triassic flysch sequence in the Pelagonian realm of Evia island (Greece), Proc. of the VIII International Congress of the Geological Society of Greece, Patras, May 1998..

Deer, W.R., Howie, R.A., and Zussman, J., 1992. An Introduction to the Rock-Forming Minerals, Essex, England, Longman, 696pp.

Engel, M., and Reischmann, T., 1998. Single Zircon geochronology of orthogneisses from Paros, Greece, $8^{\text {th }}$ International Congress of the Geological Society of Greece, Patras, XXXII(3), 91-99.

Hanson, G.N., 1978. The application of trace elements to the petrogenesis of igneous rocks of granitic composition, Earth and Planetary Science Letters, 38, 26-43.

Hey, M.H., 1954. A new review on the chlorites, Mineralogical Magazine, 224, 277-298.

Honma, H., 1974. Chemical features of biotite from metamorphic and granitic rocks of the Yanai District in the Ryoke Belt Japan, Journal of Japanese Association of Mineralogical Petrological Economic Geology, 69, 390-402.

Gregou, S., 1994. The carbonate/flysch transition and the basal units of the flysch sequence, in the Osios Loukas area, Parnassus-Ghiona Zone, Central Greece, Bulletin of the Geological Society of Greece, XXX(2), 227-247.

Karipi, S., 2004. The ophiolitic outcrops of Iti and Kallidromon. Geological study - Petrogenetic evolution - Geotectonic interpretation, Ph.D. Thesis, University of Patras, $417 \mathrm{pp}$.

Karipi, S., Tsikouras, B., and Hatzipanagiotou, K. 2006. The petrogenesis and tectonic setting of ultramafic rocks from Iti and Kallidromon Mountains, continental Central Greece: vestiges of the Pindos ocean,. Canadian Mineralogist, 44(1), 267-287.

Keupp, H., 1976. Tektonik und präorogene Stratigraphie der Flysch - Depression von Delphi Arachova (Parnass - Kiona Zone, Mittgriechenland), Zeitschrift der Deutschen Geologischen Gesellschaft, 127, 199-415.

Labotka, T.C., 1983. Analysis of compositional variations of biotite in pelitic hornfelses from northeastern Minnesota, American Mineralogist, 68, 900-914.

Maniar, P.D., and Piccoli, P.M., 1989. Tectonic discrimination of granitoids, Geological Society of America Bulletin, 101, 635-643.

Ottemann, J., and Frenzel, G., 1965. Der Chemismus der Pseudobrookite von Vulkaniten, Schweiz erische Mineralogische und Petrographische Mitteilungen, 45, 819-836. 
Papanikolaou, D., 1989. Are the medial crystalline massifs of the Eastern Mediterranean drifted Godwanian fragments? Geological Society of Greece, Special Publication, 1, 63-90.

Papastamatiou, J., 1960. La géologie de la région montagneuse du Parnassos-Kiona-Oeta, Bulletin de la Société Géologique de France, 7, 398-409.

Papastamatiou, J., Tataris, A., Vetoulis, D., Bornovas, J., Christodoulou, G., and Katsikatsos, G., 1960. Geological map of Amfissa 1:50000, I.G.S.R.

Papastamatiou, J., Vetoulis, D., and Tataris, A., 1962. Kallidromon. Géologie et correlation avec le Parnasse, Annalles Géologiques des Pays Helléniques, 5(1), 43-51.

Peacock, M.A., 1931. Classification of igneous rocks, Journal of Geology, 39, 65-67.

Pearce, J.A., Harris, N.B.W., and Tindle, A.G., 1984. Trace element discrimination diagrams for tectonic interpretation of granitic rocks, Journal of Petrology, 25, 952-983.

Pe-Piper, G., and Koukouvelas, I., 1990. Petrology and geochemistry of granitic pebbles in the Pliocene fluvial deposits of the northwest Peloponnese (Greece) and their regional significance, Neues Jahrbuch für Mineralogie-Abhandlungen, 161(3), 327-343.

Pe-Piper, G., and Koukouvelas, I., 1992. Petrology, geochemistry and regional geological significance of igneous clasts in Parnassos flysch, Amfissa area, Greece, Neues Jahrbuch für Mineralogie-Abhandlungen, 164(1), 94-112.

Richter, D., 1976. Das Flysch - Stadium der Helleniden - Ein Uberblick, Zeitschrift der Deutschen Geologischen Gesellschaft, 127, 467-483.

Richter, D., and Mariolakos, I., 1974. Neu Erkenntnisse uber die Paläogeographie des Gebietes sudwstlich Levadhia von Beginn der Flysch - Sedimantation, Prakt.Akad. Athinon, 48, 407-426.

Richter, D., and Mariolakos, I., 1975. Stratigraphische Untersuchungen an der Kreide/TertiärWende im Gebiet von Delfi-Amfissa. Amfiklia (Parnass-Giona zone Griechenland), Annalles Géologiques des Pays Helléniques, 26, 417-34.

Richter, D., and Risch, H., 1981. Die Flyschzonen Griechenlands IV. Der Flysch und seine Unterlage im Giona - Parnass - Elikon Gebirge (Parnass - Zone, Mittelgriechenland), Zeitschrift für Geologische Wissenschaften, 9, 645-673.

Richter, D., Mihm, A., and Müller, C., 1997. Die pelagonischen Deckenreste auf dem Flysch des Ostpindos-Synklinoriums (Pindos-Zone) westlich des Iti-Gebirges (Mittelgriechenland), Zeitschrift der Deutschen Geologischen Gesellschaft, 148(2), 237-246.

Solakius, N., 1994. Depositional changes in the Parnassus - Ghiona Zone, Central Greece, during the Paleocene, Bulletin of the Geological Society of Greece, XXX(2), 201-205.

Solakius, N., and Pomoni-Papaioannou, F., 1992. Planktonik foraminiferal biostratigraphy and sequence stratigraphy of the carbonate-flysch sequence at Prossilion in the Parnassus Ghiona Zone, Central Greece, Geological Society of Greece Bulletin, 28(3), 75-86.

Stampfli, G.M., 1996. The Intra-Alpine terrain: A Paleotethyan remnant in the Alpine Variscides, Eclogae Geologicae Helveticae, 89(1), 13-42.

Stampfli, G.M., Mosar, J., De Bono, A., and Vavassis, I., 1998. Late Paleozoic, Early Mesozoic Plate Tectonics of the Western Tethys, Geological Society of Greece, Special Publication, Bulletin of the Geological Society of Greece, 32(1), 113-120.

Streckeisen, A., and Le Maitre, R.W., 1979. A chemical approximation to the modal QAPF classification of the igneous rocks, Neues Jahrbuch für Mineralogie-Abhandlungen, 136, 169206. 
Sun, S.S., and McDonough, W.F., 1989. Chemical and isotopic systematics of oceanic basalts: implications for mantle composition and processes. In A.D. Saunders and M.J. Norry (eds), Magmatism in the Ocean Basins. Geological Society of London, Special Publication, 42, 313-345pp.

Thompson, G.M., Malpas, J., and Smith, I.E.M., 1997. The geochemistry of tholeiitic and alkalic plutonic suites within the Northland Ophiolite, northern New Zealand, magmatism in a back arc basin, Chemical Geology, 142, 113-123.

Vavassis, I., De Bono, A., Valloton, A., Stampfli, G.M., and Amelin, Y., 1999. New U-Pb and ArAr geochronological data from Pelagonia basement in Evia (Greece): geodynamic implications for the Paleotethys subduction, EUG 10, Strasbourg, 314pp.

White, A.J.R., and Chappell, B.W., 1977. Ultrametamorphism and granitoid genesis, Tectonophysics, 43, 7-22.

White, A.J.R., and Chappell, B.W., 1983. Granitoid types and their distribution in the Lachlan Fold Belt, Southeastern Australia. In J.A. Roddick (ed.), Circum - Pacific Plutonic Terranes, Geological Society of America Memoir., 21-34pp.

Wigniolle, E., 1977a. Contribution à l'étude géologique du massif de l'Iti (Grèce continentale), Thèse 3 e cycle, Université de Lille, 239pp.

Wigniolle, E., 19977b. Données nouvelles sur la géologie du massif de l'Iti (Grèce continentale), Annalles de la Société Géologique du Nord, 47(3), 239-251.

Wilson, M., 1989. Igneous petrogenesis, Unwin London, 466pp.

Yarwood, G.A., and Aftalion, M., 1976. Field relations and U-Pb geochronology of a granite from the Pelagonian zone of the Hellenides (High Pieria, Greece), Bulletin de la Société Géologique de France, XVIII(2), 259-264. 